\title{
Ipsilateral hip pain and femoral shaft fractures: is there any relationship?
}

\author{
Ramadan Özmanevra, M.D., ${ }^{1}$ Nihat Demirhan Demirkıran, M.D., ${ }^{2}$

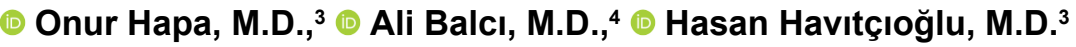

\author{
${ }^{1}$ Department of Orthopaedics and Traumatology, University of Kyrenia Faculty of Medicine, Kyrenia-TRNC \\ ${ }^{2}$ Department of Orthopaedics and Traumatology, Kütahya University of Health Sciences Evliya Çelebi Training and \\ Research Hospital, Kütahya-Turkey \\ ${ }^{3}$ Department of Orthopaedics and Trauma Surgery, Dokuz Eylul University Faculty of Medicine, İzmir-Turkey \\ ${ }^{4}$ Department of Radiology, Dokuz Eylul University Faculty of Medicine, İzmir-Turkey
}

\begin{abstract}
BACKGROUND: High-energy traumas are common occurrences worldwide. The rate of overlooked neck fractures in polytrauma cases is also high. Previous studies have shown that articular hip pathologies, particularly neck fractures, are associated with fractures of the femoral shaft. This study sets out to describe cases of intra-articular hip pathology following traumatic femoral shaft fracture. Thus, the present study aims to investigate the relationship between ipsilateral hip pain and femoral shaft fractures.

METHODS: Patients who were diagnosed with a fracture of the femur shaft and who were operated on (intramedullary fixation or plate) were included in this study. Patients with pathologic fractures, femoral neck fractures, femoral intertrochanteric fractures, or pelvic fractures were excluded. Patients with at least six months of follow-up and who were capable of independent walking without support were grouped according to AO/OTA fracture classification. Patients were questioned for deep anterior groin pain, and physical examination tests and hip imaging (X-ray and MR arthrography) were performed by calling patients with the indicated complaints.

RESULTS: The presence of labral tears were noted in two patients. The incidence of osseous bump of the femoral neck identified by MR arthrography (MRA) was found in three of 16 hips. Assessment of the presence of gluteal tendinosis or tear and herniation pit identified three of 16 hips. The presence of osteophytes was noted in one patient. MRA identified three of 16 hips with more than one type of intra-articular pathology. Two patients with an osseous bump of the femoral neck were also diagnosed with additional hip pathology as herniation pit.
\end{abstract}

CONCLUSION: Anterior groin pain in patients with a history of femoral shaft fracture is not always related to implants. Orthopedic surgeons should become suspicious in cases of intra-articular hip pathology in patients who have persistent hip pain after severe lower extremity trauma.

Keywords: Femoral shaft; femur fracture; hip pathology; intra-articular; MR arthrography.

\section{INTRODUCTION}

High-energy trauma causes concurrent ipsilateral hip fractures and occurs in $1-6 \%$ of fractures of the femoral shaft. [1-3] The clearer deformity and shaft fracture pain usually cover the femoral neck fracture in the same extremity, and make diagnosis and treatment of these fractures diffi- cult. The rate of overlooked femoral neck fracture in polytrauma cases varies from $19 \%$ to $50 \%$; $[2,4-6]$ however, with the growing awareness and advances in scanning, this rate is declining. ${ }^{[7,8]}$ Severe complications, such as femoral head osteonecrosis, make it even more important to diagnose and treat these injuries as early as possible. Khanna et al. ${ }^{[9]}$ investigated intra-articular hip pathologies associated with

Cite this article as: Özmanevra R, Demirkıran ND, Hapa O, Balcı A, Havıtçığlu H. Ipsilateral hip pain and femoral shaft fractures: is there any relationship? Ulus Travma Acil Cerrahi Derg 2019;25:514-519.

Address for correspondence: Ramadan Özmanevra, M.D.

Girne Üniversitesi, Dr. Suat Gunsel Hastanesi, 99320 Girne, KKTC

Tel: +90 392 - 4449939 E-mail: rozmanevra@gmail.com

Ulus Travma Acil Cerrahi Derg 2019;25(5):5I4-519 DOI: 10.5505/tjtes.2018.52543 Submitted: 19.09.2018 Accepted: 19.12.2018 Online: 05.08.2019

Copyright 2019 Turkish Association of Trauma and Emergency Surgery 
acute hip traumas in their prospective case series and they found a high incidence of ipsilateral injuries, such as labral tears (93\%), osteochondral lesions (49\%) and intra-articular step-off (38\%).

Based on the findings previous studies obtained, we predict that patients with femoral shaft fractures may also have unilateral intra-articular pathologies that may not be noticed at initial evaluation. Particularly in patients who have complaints of anterior groin pain with a history of femoral shaft fracture, we think that this pain may be due to intra-articular hip pathologies that develop after trauma. Conventional radiographs may be inadequate for diagnosing these injuries (such as FAl, chondral injury, labral tear,) and MR arthrography has been proven to be a gold standard in recent studies. [10-13] Therefore, we set out to investigate intra-articular hip pathologies of patients who developed deep anterior groin pain in follow-up after femoral shaft fracture surgery, using physical examination X-rays and MR arthrography.

Patients who were diagnosed with a fracture of the femoral shaft and who had been operated on (intramedullary fixation or plate) were included in this study. Patients with pathologic fractures, femoral neck fractures, femoral intertrochanteric fractures, or pelvic fractures were excluded. Patients with at least six months of follow-up and who were capable of independent walking without support were grouped according to AO/OTA fracture classification. Patients were questioned for deep anterior groin pain, and physical examination tests and hip imaging (X-ray and MR arthrography) were performed by calling patients with the indicated complaints.

The research question of our study was 'what is the frequency of unnoticed ipsilateral hip joint injuries following femoral shaft fractures?'. Our hypothesis was 'after femur shaft fractures, ipsilateral intraarticular hip pathologies are seen, and the diagnosis is frequently overlooked at initial evaluation.' This study aims to describe cases of intra-articular hip pathologies following traumatic femoral shaft fracture. We aimed to evaluate the correlation between intra-articular hip pathologies and femoral shaft fractures.

\section{MATERIALS AND METHODS}

Patients who were diagnosed with a fracture of the femur shaft and who had been operated on (intramedullary fixation or plate application) were included in this study. Patients with pathologic fractures, femoral neck fractures, femoral intertrochanteric fractures, or pelvic fractures were excluded. Patients with at least six months of follow-up and who were capable of independent walking without support were grouped according to AO/OTA fracture classification. Patients were questioned for deep anterior groin and hip pain. Physical examination tests and hip imaging (X-ray and $M R$ arthrography) were performed by calling patients with the indicated complaints. For this purpose, ethical approval was obtained. This study was supported by the Scientific Research Project Unit of Dokuz Eylul University.

A retrospective review was performed to identify 145 patients who had undergone femoral shaft fracture surgery within the previous six months. Twenty-five patients with persistent groin pain or limping following fixation of an ipsilateral femoral shaft fracture were reported. A written report was prepared by asking the patient about the pain or limping via telephone. Sixteen of the patients agreed to visit the hospital for examination. All patients reported groin pain that was not present before the surgery. All patients signed an informed consent form. The diagnosis was verified based on clinical examination findings and tests. X-rays (Pelvis AP, $45^{\circ}$ modified Dunn lateral radiographs, false profile) and $M R I$ arthrography (MRA) were applied to the included patients. Following the $M R$ imaging, the joint injection was performed. Patients were placed on a fluoroscopic table for a hip puncture, and internal rotation was maintained using a bolster under the knees with both feet taped together. A direct anterior or anterolateral approach to the hip was used. Intraarticular needle position was documented by injecting a small amount of iodinated contrast material. After confirming the intraarticular position, Gadopentetate dimeglumine (Magnevist; Berlex Laboratories, Wayne, NJ) was injected. Objective assessment was performed at the radiology department.

Data were collected, which included the assessment of labral tears, subchondral cysts, ligamentum teres tears, labral/paralabral cysts, acetabular bone edema, fibrocystic changes of the femoral head/neck, rim fracture, osseous bump of the femoral neck, chondral lesions, osteophytes, transverse ligament tears, bursitis, avascular necrosis, adductor longus tendinosis, gluteal tendinosis or tear, femoral bony abnormalities and herniation pit.

Mean, standard deviation, median lowest, highest, frequency and ratio values were used in descriptive statistics of the data. The distribution of variables was measured with the Kolmogorov-Simirnov test. Mann-Whitney $U$ test was used for quantitative independent data analysis. Chi-square test was used for the analysis of qualitative independent data, and Fischer test was used when the chi-square test conditions were not provided. SPSS 22.0 program was used in the analysis.

\section{RESULTS}

Sex distribution consisted of six women and ten men. The average age of the patients was 37.8 years (range 18-81). The average time from trauma to study was 28.3 months. Four of the patients were applied plate and 12 patients were applied intramedullary nail.

The presence of labral tear was noted in two patients (Fig. I). The incidence of an osseous bump of the femoral neck iden- 


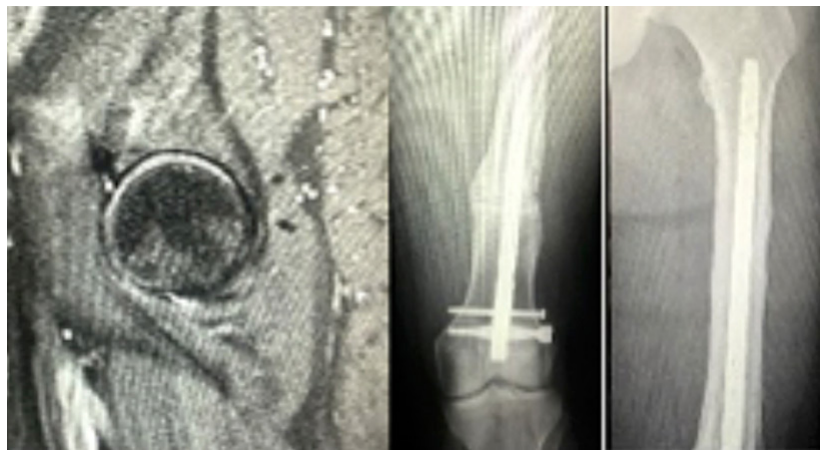

Figure 1. The MRI and X-rays of a patient with labral tear.

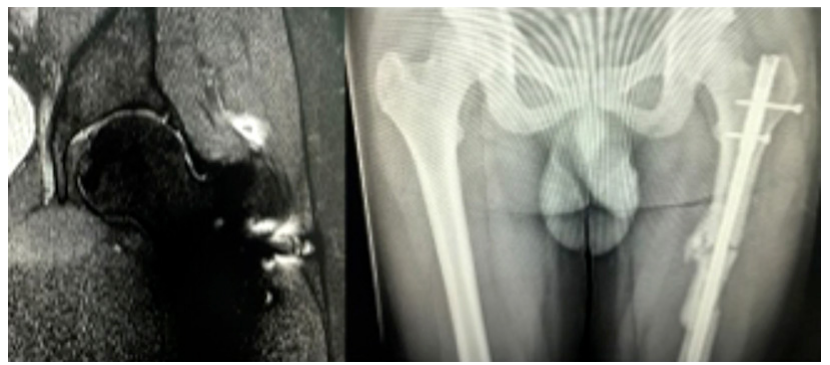

Figure 2. The MRI and pelvis AP postoperative $2^{\text {nd }}$ day of the patient showed gluteal tendinosis.

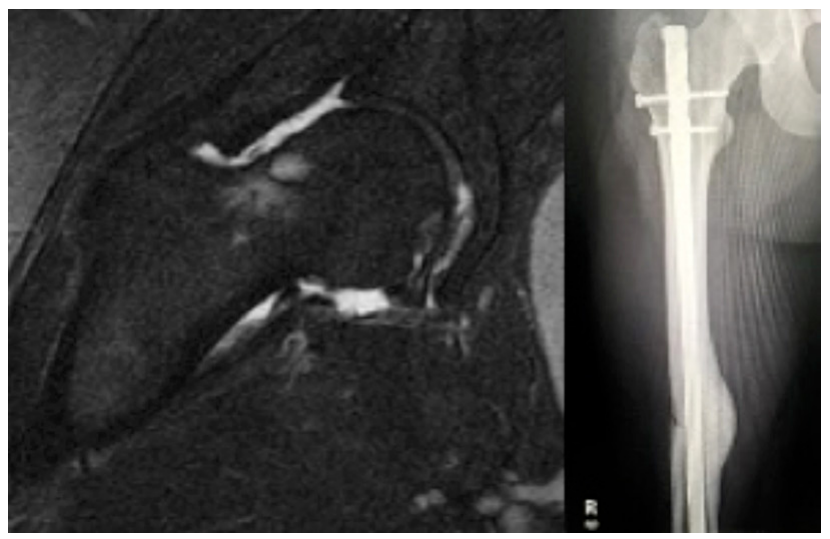

Figure 3. The MRI and X-ray of the patient with herniation pit.

tified by MRA was three of 16 hips. In the assessment of the presence of gluteal tendinosis or tear (Fig. 2) and herniation pit, three of 16 hips were identified (Fig. 3). The presence of osteophytes was noted in I patient. MRA identified three of 16 hips as having more than one type of intra-articular pathology (Table I). Two patients with osseous bump of the femoral neck were also diagnosed with additional hip pathology as herniation pit. Fifty percent of hips were diagnosed radiologically with intra-articular pathology (Table I). Overlooked femoral neck fracture was not detected. The average alfa angle which was measured was 43,9 and lateral centre edge angle was 35,3 .

No significant difference was found between the pathologies and angles of the hip in comparison with fracture types $(p>0.05)$ (Table 2). No difference was found between the types of operations performed ( $p>0.05$ ) (Table 3).
Table I. Patients' demographics and detected hip pathologies

\begin{tabular}{lccccc}
\hline & Min-Max & Median & Mean \pm SD & n & $\%$ \\
\hline Age & $18-8 \mid$ & 27.0 & $37.8 \pm 20.6$ & & \\
Sex & & & & & \\
$\quad$ Female & & & & 6 & 37.5 \\
$\quad$ Male & & & & 10 & 62.5
\end{tabular}

Fracture type

$\begin{array}{lcc}\text { Oblique } & 2 & 12.5 \\ \text { Transvers } & 14 & 87.5 \\ \text { peration type } & & \\ \text { Plate } & 4 & 25.0 \\ \text { Intramedullary nail } & 12 & 75.0\end{array}$

Alfa angle (degree) $\quad 29-78 \quad 41.5 \quad 43.9 \pm 11.4$

Lateral center

edge angle (degree) $\quad 24-46 \quad 35.5 \quad 35.3 \pm 5.8$

Labral tear

$14 \quad 87.5$

$(+)$

$2 \quad 12.5$

Osseous bump of

the femoral neck

$(-)$

$13 \quad 81.3$

$(+)$

$3 \quad 18.8$

Osteophytes

$15 \quad 93.8$

I 6.3

Gluteal tendinosus or tear

$(+)$

Herniation pit

$13 \quad 81.3$

$(+)$

$3 \quad 18.8$

Min: Minimum; Max: Maximum; SD: Standard deviation.

\section{DISCUSSION}

Our study revealed an ipsilateral hip pathology in half of the patients with hip and deep groin pain after femoral shaft fracture, regardless of fracture type or treatment modality. The source of persistent hip pain during the recovery period in patients with traumatic femoral shaft fracture is not always obvious. In some patients, it is present despite appropriate healing of the fracture. Implant removal may be recommended in some cases, but this is not always successful. ${ }^{\left[{ }^{[1]}\right]}$ The causes of persistent symptoms can be multifactorial. The probability of an intra-articular hip pathology is often neglected. With the high-energy injuries, the possibility of complaints depends on both femoral shaft fracture and pathology of the hip joint re- 
Table 2. The comparison of fracture types

\begin{tabular}{|c|c|c|c|c|c|c|c|c|c|}
\hline & \multicolumn{4}{|c|}{ Fracture type-Oblique } & \multicolumn{4}{|c|}{ Fracture type-Transvers } & \multirow[t]{2}{*}{$\mathbf{p}$} \\
\hline & Mean $\pm S D$ & $\mathbf{n}$ & $\%$ & Median & Mean $\pm S D$ & $\mathbf{n}$ & $\%$ & Median & \\
\hline Alfa angle (degree) & $58.0 \pm 28.3$ & & & 58.0 & $41.9 \pm 7.3$ & & & 41.5 & $0.524^{\mathrm{m}}$ \\
\hline Lateral center edge angle (degree) & $39.0 \pm 5.7$ & & & 39.0 & $34.7 \pm 5.9$ & & & 35.0 & $0.340^{\mathrm{m}}$ \\
\hline \multicolumn{10}{|l|}{ Labral tear } \\
\hline$(-)$ & & 2 & 100 & & & 12 & 85.7 & & $1.000^{x^{2}}$ \\
\hline$(+)$ & & 0 & 0.0 & & & 2 & 14.3 & & \\
\hline \multicolumn{10}{|l|}{ Osseous bump of the femoral neck } \\
\hline$(-)$ & & 1 & 50.0 & & & 12 & 85.7 & & $0.350^{x^{2}}$ \\
\hline$(+)$ & & 1 & 50.0 & & & 2 & 14.3 & & \\
\hline \multicolumn{10}{|l|}{ Osteophytes } \\
\hline$(-)$ & & 2 & 100 & & & 13 & 92.9 & & $1.000^{x^{2}}$ \\
\hline$(+)$ & & 0 & 0.0 & & & 1 & 7.1 & & \\
\hline \multicolumn{10}{|l|}{ Gluteal tendinosus or tear } \\
\hline$(-)$ & & 2 & 100 & & & 11 & 78.6 & & $1.000^{x^{2}}$ \\
\hline$(+)$ & & 0 & 0.0 & & & 3 & 21.4 & & \\
\hline \multicolumn{10}{|l|}{ Herniation pit } \\
\hline$(-)$ & & 2 & 100 & & & II & 78.6 & & $1.000^{x^{2}}$ \\
\hline$(+)$ & & 0 & 0.0 & & & 3 & 21.4 & & \\
\hline
\end{tabular}

mMann-Whitney $U$ test; ${ }^{x^{2}}$ Chi-square test (Fischer test). SD: Standard deviation.

Table 3. The comparison of operation types

\begin{tabular}{|c|c|c|c|c|c|c|c|c|c|}
\hline & \multicolumn{4}{|c|}{ Operation type-Plate } & \multicolumn{4}{|c|}{ Operation type-IMN } & \multirow[t]{2}{*}{$\mathbf{p}$} \\
\hline & Mean $\pm S D$ & $\mathbf{n}$ & $\%$ & Median & Mean $\pm S D$ & $\mathbf{n}$ & $\%$ & Median & \\
\hline Alfa angle (degree) & $51.0 \pm 18.7$ & & & 44.0 & $41.6 \pm 7.5$ & & & 41.5 & $0.504^{\mathrm{m}}$ \\
\hline Lateral center edge angle (degree) & $37.8 \pm 3.6$ & & & 36.5 & $34.4 \pm 6.3$ & & & 33.5 & $0.208^{m}$ \\
\hline \multicolumn{10}{|l|}{ Labral tear } \\
\hline$(-)$ & & 3 & 75.0 & & & II & 91.7 & & $0.450^{x^{2}}$ \\
\hline$(+)$ & & 1 & 25.0 & & & 1 & 8.3 & & \\
\hline \multicolumn{10}{|l|}{ Osseous bump of the femoral neck } \\
\hline$(-)$ & & 3 & 75.0 & & & 10 & 83.3 & & $1.000^{x^{2}}$ \\
\hline$(+)$ & & 1 & 25.0 & & & 2 & 16.7 & & \\
\hline \multicolumn{10}{|l|}{ Osteophytes } \\
\hline$(-)$ & & 3 & 75.0 & & & 12 & 100.0 & & $0.250^{x^{2}}$ \\
\hline$(+)$ & & 1 & 25.0 & & & 0 & 0.0 & & \\
\hline \multicolumn{10}{|l|}{ Gluteal tendinosus or tear } \\
\hline$(-)$ & & 3 & 75.0 & & & 10 & 83.3 & & $1.000^{x^{2}}$ \\
\hline$(+)$ & & 1 & 25.0 & & & 2 & 16.7 & & \\
\hline \multicolumn{10}{|l|}{ Herniation pit } \\
\hline$(-)$ & & 4 & 100 & & & 9 & 75.0 & & $0.529^{x^{2}}$ \\
\hline$(+)$ & & 0 & 0.0 & & & 3 & 25.0 & & \\
\hline
\end{tabular}

mMann-Whitney $U$ test; ${ }^{{ }^{2}}$ Chi-square test (Fischer test). IMN: Intramedullary nail; SD: Standard deviation. 
mains unclear. ${ }^{[15,16]}$ These pathologies may lead to persistent hip pain and disability. Femoral shaft fractures arise from considerable trauma, so these patients often have other injuries given that common comorbid injuries femoral neck fracture and soft tissue damage of the knee are both documented in the literature. ${ }^{[17,18]}$ Burnett et al. ${ }^{[19]}$ concluded that when a femoral shaft fracture occurs, significant attention has not been paid to the possibility of a soft tissue injury of the hip. This may be due in part to the initial severity of the trauma, as well as general pain related to the fracture or its fixation, complicating the diagnosis of labral pathology. In our study, we detected at least one type of intraarticular pathology in half of the patients with femoral shaft fracture and hip pain after a fracture. Three of these patients had more than one articular pathology.

Orthopedic surgeons should become suspicious of labral pathology in patients who have persistent hip pain after severe lower extremity trauma. MRI arthrography is more specific and more sensitive than conventional MRI. Studies have shown that MRI arthrography is the most definitive and reliable diagnostic tool to confirm the presence of a labral tear. $^{[20-22]}$ In patients with ipsilateral hip joint complaints, evaluation of the hip with MRI arthrography after completing clinical and radiographic examination may be required. Intraarticular hip pathology can be confirmed by performing hip arthroscopy, and hip arthroscopy may also help to eliminate the source of pain.

High energy trauma can subluxate or dislocate adjacent joints and cause significant intra-articular trauma. Similar entities have also been shown in the knee. Several studies have documented ligamentous knee damage in conjunction with femoral fractures. ${ }^{[23,24]}$

Our patient group consisted of patients with femoral shaft fractures after high energy trauma. Only two of our patients had an oblique fracture. However, no significant difference was found between fracture type and intraarticular pathologies.

Twelve patients were treated with IMN and four patients received plate application in our study group. No significant difference was found between operation types and intraarticular pathologies. None of the patients underwent implant removal because of pain. Removal of the implant is most commonly applied in patients with persistent hip pain following ORIF of a femoral shaft fracture. Implant removal successfully alleviates pain in many cases, but studies documented cases in which pain was not relieved. Dodenhoff et al. reported the incidence of residual femoral pain in 80 patients who were treated for traumatic femoral fracture with a Grosse-Kempf nail. Seventeen patients had the nail removed due to pain, and of these, six (35\%) patients continued to experience the pain. This result suggests that if the pain is not resolved after implant removal, consideration should be given to soft tissue and intra-articular pa-thology of the adjacent joints. Magnetic resonance imaging provides highly sensitive and accurate resolution of the labrum and associated tissue, making it an effective tool for identifying the location and magnitude of a labral tear. ${ }^{[14]}$

In our study, eight of the sixteen patients presented intraarticular hip pathologies with persistent hip and groin pain after femoral shaft fracture. We found a correlation between femoral shaft fracture and intra-articular hip pathologies.

One of the limitations of our study is the amount of included patients. The number of patients is insufficient to detect the frequency of the ipsilateral hip joint injuries following femoral shaft fractures. The weakness of this study is that it was a retrospective study. However, the study is enhanced by the use of a blinded musculoskeletal radiologist to quantify the pathologic findings from the imaging to provide valuable insights into the literature. We hope further investigations may lead to insightful information about this research topic.

\section{Conclusions}

In conclusion, intra-articular hip pathologies can be detected in patients who have femoral shaft fractures. Anterior groin and hip pain in patients with a history of femoral shaft fracture are not always related to implants. Orthopedic surgeons should become suspicious of intra-articular hip pathology in patients who have persistent hip pain after severe lower extremity trauma. It should be kept in mind that intraarticular injuries other than femur neck fracture may develop with the femoral shaft fracture.

\section{Conflict of interest: None declared.}

\section{REFERENCES}

1. Abalo A, Dossim A, Ouro Bangna AF, Tomta K, Assiobo A, Walla A. Dynamic hip screw and compression plate fixation of ipsilateral femoral neck and shaft fractures. J Orthop Surg (Hong Kong) 2008;16:35-8.

2. Swiontkowski MF. Ipsilateral femoral shaft and hip fractures. Orthop Clin North Am 1987;18:73-84.

3. Zettas JP, Zettas P. Ipsilateral fractures of the femoral neck and shaft. Clin Orthop 1981;160:63-73. [CrossRef]

4. Swiontkowski MF, Hansen ST Jr, Kellam J. Ipsilateral fractures of the femoral neck and shaft. A treatment protocol. J Bone Joint Surg Am 1984;66:260-8. [CrossRef]

5. Bennett FS, Zinar DM, Kilgus DJ. Ipsilateral hip and femoral shaft fractures. Clin Orthop Relat Res 1993;296:168-77. [CrossRef]

6. Delaney WM, Street DM. Fracture of femoral shaft with fracture of neck of same femur; treatment with medullary nail for shaft and Knowles pins for neck. J Int Coll Surg 1953;19:303-12.

7. Lawson E, Madougou S, Chigblo P, Quenum G, Ouangré A, Tidjani F, et al. Ipsilateral proximal and shaft femoral fractures. Chin J Traumatol 2017;20:155-7. [CrossRef]

8. Yang KH, Han DY, Park HW, Kang HJ, Park JH. Fracture of the ipsilateral neck of the femur in shaft nailing. The role of $\mathrm{CT}$ in diagnosis. J Bone Joint Surg Br 1998;80:673-8. [CrossRef] 
9. Khanna V, Harris A, Farrokhyar F, Choudur HN, Wong IH. Hip arthroscopy: prevalence of intra-articular pathologic findings aftertraumatic injury of the hip. Arthroscopy 2014;30:299-304. [CrossRef]

10. Chan YS, Lien LC, Hsu HL, Wan YL, Lee MS, Hsu KY, et al. Evaluating hip labral tears using magnetic resonance arthrography: a prospective study comparing hip arthroscopy and magnetic resonance arthrography diagnosis. Arthroscopy 2005;21:1250. [CrossRef]

11. Toomayan GA, Holman WR, Major NM, Kozlowicz SM, Vail TP. Sensitivity of MR arthrography in the evaluation of acetabular labral tears. AJR Am J Roentgenol 2006;186:449-53. [CrossRef]

12. Petersilge CA, Haque MA, Petersilge WJ, Lewin JS, Lieberman JM, Buly R. Acetabular labral tears: evaluation with MR arthrography. Radiology 1996;200:231-5. [CrossRef]

13. Leunig M, Werlen S, Ungersböck A, Ito K, Ganz R. Evaluation of the acetabular labrum by MR arthrography.J Bone Joint Surg Br 1997;79:230 4. [CrossRef]

14. Dodenhoff RM, Dainton JN, Hutchins PM. Proximal thigh pain after femoral nailing. Causes and treatment. J Bone Joint Surg Br 1997;79:738-41. [CrossRef]

15. Milenković S, Mitković M, Saveski J, Micić I, Stojiljković P, Stanojković $\mathrm{M}$, et al. Avascular necrosis of the femoral head in the patients with posterior wall acetabular fractures associated with dislocations of the hip. [Article in Serbian]. Acta Chir Iugosl 2013;60:65-9. [CrossRef]

16. Giannoudis PV, Kontakis G, Christoforakis Z, Akula M, Tosounidis T, Koutras C. Management, complications and clinical results of femoral head fractures. Injury 2009;40:1245-51. [CrossRef]
17. Tornetta P 3rd, Kain MS, Creevy WR. Diagnosis of femoral neck fractures in patients with a femoral shaft fracture. Improvement with a standard protocol. J Bone Joint Surg Am 2007;89:39-43. [CrossRef]

18. Dickson KF, Galland MW, Barrack RL, Neitzschman HR, Harris MB, Myers L, et al. Magnetic resonance imaging of the knee after ipsilateral femur fracture. J Orthop Trauma 2002;16:567-71. [CrossRef]

19. Burnett RS, Della Rocca GJ, Prather H, Curry M, Maloney WJ, Clohisy JC. Clinical presentation of patients with tears of the acetabular labrum.J Bone Joint Surg Am 2006;88:1448-57. [CrossRef]

20. Byrd JW, Jones KS. Diagnostic accuracy of clinical assessment, magnetic resonance imaging, magnetic resonance arthrography, and intra-articular injection in hip arthroscopy patients. Am J Sports Med 2004;32:166874. [CrossRef]

21. Kelly BT, Williams RJ 3rd, Philippon MJ. Hip arthroscopy: current indications, treatment options, and management issues. Am J Sports Med 2003;31:1020-37. [CrossRef]

22. Freedman BA, Potter BK, Dinauer PA, Giuliani JR, Kuklo TR, Murphy KP. Prognostic value of magnetic resonance arthrography for Czerny stage II and III acetabular labral tears. Arthroscopy 2006;22:742-7. [CrossRef]

23. Emami Meybodi MK, Ladani MJ, Emami Meybodi T, Rahimnia A, Dorostegan A, Abrisham J, et al. Concomitant ligamentous and meniscal knee injuries in femoral shaft fracture. J Orthop Traumatol 2014;15:359. [CrossRef]

24. Moore TM, Patzakis MJ, Harvey JP Jr. Ipsilateral diaphyseal femur fractures and knee ligament injuries. Clin Orthop Relat Res 1988;232:1829. [CrossRef]

\section{ORİJINAL ÇALIŞMA - ÖZET}

\section{İpsilateral kalça ağrısı ve femur şaft kırıkları: Herhangi bir ilişki var mı?}

\section{Dr. Ramadan Özmanevra, ${ }^{1}$ Dr. Nihat Demirhan Demirkıran, ${ }^{2}$ Dr. Onur Hapa, ${ }^{3}$ Dr. Ali Balcı, ${ }^{4}$ Dr. Hasan Havıtçığlu ${ }^{3}$}

${ }^{1}$ Girne Üniversitesi Tıp Fakültesi, Ortopedi ve Travmatoloji Anabilim Dalı, Girne-KKTC

${ }^{2}$ Kütahya Sağlık Bilimleri Üniversitesi Eğitim ve Araştırma Hastanesi, Ortopedi ve Travmatoloji Anabilim Dalı, Kütahya

${ }^{3}$ Dokuz Eylül Üniversitesi Tıp Fakültesi, Ortopedi ve Travmatoloji Anabilim Dalı, İzmir

${ }^{4}$ Dokuz Eylül Üniversitesi Tıp Fakültesi, Radyoloji Anabilim Dalı, İzmir

AMAÇ: Yüksek enerjili travmalar dünya çapında yaygın karşılaşılan olaylardır. Politravma olgularında gözden kaçan boyun kırıklarının oranı da yüksektir. Daha önce yapılan çalışmalar artiküler (eklem içi) kalça patolojilerinin, özellikle de boyun kırıklarının femoral şaft kırıkları ile ilişkili olduğunu göstermiştir. Bu çalışmanın amacı travmatik femoral şaft kırığııı takiben eklem içi kalça patolojisi olgularını tanımlamaktır. Bu çalışmanın araştırma sorusu "Femur şaft kırıklarından sonra femur boynu kırılmayan hastaların kalça eklemlerinde ne oluyor?" dur.

GEREÇ VE YÖNTEM: Femur şaft kııı̆ı tanısı konan ve ameliyat edilen hastalar (intramedüller fiksasyon veya plak uygulaması) çalışmaya alındı. En az altı ay takip edilen ve desteksiz bağımsız yürüme yeteneğine sahip hastalar AO/OTA kırık sınıflamasına göre gruplandırıldı. Hastalara derin anterior kasık ağrısı soruldu ve belirtilen şikayetleri olan hastalar aranarak fizik muayene ve kalça görüntüleme (X-ray ve manyetik rezonans artrografi [MRA]) yapıldı.

BULGULAR: İki hastada labral yırtık tespit edildi. MRA ile femur boynu osseöz bump 16 kalçadan üçünde bulundu. Gluteal tendinosis veya gözyaşı ve herniasyon pit (çukurunun) varlığının değerlendirilmesi, 16 kalçadan üçünde tespit edilmiştir. Bir hastada osteofit varlığı belirlendi. MRA ile, 16 kalçadan üçünde birden fazla tipte intra-artiküler (eklem içi) patoloji tanımlandı. Femur boynu osseöz bumpı olan iki hastaya da herniasyon pit olarak ek kalça patolojisi tanısı konuldu.

TARTIŞMA: Femur şaft kırı̆̆ı öyküsü olan hastalarda kasık önü ağrısı her zaman implantlarla ilişkili değildir. Ortopedik cerrahlar, şiddetli alt ekstremite travması sonrası kalııı kalça ağrısı olan hastalarda eklem içi kalça patolojilerinden şüphelenmelidirler

Anahtar sözcükler: Eklemiçi; femur kırı̆ı̆; femur şaft; kalça patolojisi; manyetik rezonans artrografi.

Ulus Travma Acil Cerrahi Derg 2019;25(5):5।4-519 doi: 10.5505/tjtes.2018.52543 